\title{
Music in the Age of Mechanical Reproduction: Drama, Gramophone, and the Beginnings of Tamil Cinema
}

\section{STEPHEN PUTNAM HUGHES}

\begin{abstract}
During the first half of the twentieth century, new mass media practices radically altered traditional cultural forms and performance in a complex encounter that incited much debate, criticism, and celebration the world over. This essay examines how the new sound media of gramophone and sound cinema took up the live performance genres of Tamil drama. Professor Hughes argues that south Indian music recording companies and their products prefigured, mediated, and transcended the musical relationship between stage drama and Tamil cinema. The music recording industry not only transformed Tamil drama music into a commodity for mass circulation before the advent of talkies but also mediated the musical relationship between Tamil drama and cinema, helped to create film songs as a new and distinct popular music genre, and produced a new mass culture of film songs.
\end{abstract}

$\mathrm{T}$ HERE CAN BE LITTLE doubt about the popularity and prominence of film songs as a defining and enduring characteristic of commercial Indian cinema. From the first production of Indian sound films in 1931, film songs have been a heavily featured component of cinematic entertainment, both within films and in wider public circulation. ${ }^{1}$ Tamil films, a south Indian regional cinema, share this musical proclivity. During the first decade of Tamil cinema, it was common for a film to devote two hours out of a total running time of three hours to accommodate fifty or sixty song sequences. Some early Tamil films boasted as many as a hundred songs in their advertisements. Though the number of songs in Tamil films has gradually decreased over the last century to about five or six at present, they are still an indispensable part of all commercially viable films. A Tamil film without songs is a rare exception. Out of a total of

Stephen Putnam Hughes (sh37@soas.ac.uk) is a lecturer in the Department of Anthropology and Sociology, School of Oriental and African Studies, University of London.

${ }^{1}$ In this essay, I use the terms film music and film songs interchangeably to refer to an isolated vocal performance of a song sequence within the narrative of a feature film. Following contemporary usage in the south Indian press, these terms do not refer to background music or songs, which may accompany dramatic or action sequences. I realize that there are analytic problems in using the terms music and songs as equivalent, but for the purposes of this essay, I have chosen to defer to my historical sources. 


\section{Stephen Putnam Hughes}

over 4,000 Tamil feature films produced since 1931, only a handful are without any songs.

Not only have film songs dominated the Tamil film form, they have also moved beyond films through other media to set the standard for all popular Tamil music. For more than seventy years, the vast majority of all commercially recorded and popularly enjoyed Tamil music has been that derived from the cinema. At present, film songs cut a wide and unmistakable swath through all commercial entertainment media in Tamil. Film songs are now the common referent for a vast media network. Through the cinema, radio, television, videos, audiocassettes, loudspeakers, the Internet, and digital media, film songs are the most commonly reproduced, consumed, and mobile product in the Tamil culture industry. Some scholars have even suggested this predominance of song marks the uniqueness of Indian cinema compared to other national cinema traditions (Chandavarkar 1987; Baskaran 1991, 1996).

This essay takes up the question of why film songs were so important to Tamil cinema during the 1930s, when new sound technology first enabled film as a kind of musical address. I look at a changing set of relations between Tamil musical drama, the gramophone industry, and the beginnings of Tamil cinema as parallel and mutually constitutive media practices in the artistic creation and material production of a mass culture of film songs. It is widely acknowledged that the intensive use of songs and music in early Indian cinema can be traced, for the most part, to their continuity with the already established musical forms and conventions of the stage (Renade 1980; Barnouw and Krishnaswamy 1980; Chandavarkar 1987; Baskaran 1991, 1996; Manuel 1993). However, as all of these authors have attested, drama music was not alone in contributing to the music of Indian sound cinema. Drama music, which was already a mixture of different kinds of music_classical, folk, comic, and devotional_was part of a wide musical diffusion into Indian sound cinema. However, when trying to explain why the first Indian talkies featured songs as the main-if not the defining-appeal of their entertainment, musical drama is the most obvious and widely accepted connection. Taking this as a starting point, this essay seeks to complicate this conventional story by adding another mass media, the gramophone, into the musical equation between drama and the beginnings of Tamil cinema.

I return to this drama-to-cinema equation through an alternative genealogy of how the gramophone industry intervened to help make Tamil cinema musical during the 1930s. By examining the changing relationships between musical drama, the gramophone business, and Tamil cinema during the 1920s and 1930s in south India, I consider how and to what extent south Indian music recording companies and products prefigured, mediated, and transcended the musical relationship between stage drama and Tamil cinema. The main analytic task is plot how the new sound media of gramophone and sound cinema took up the already existing live performance genres of Tamil drama and, in so doing, how these new media worked together to create and sustain a mass culture of 
film songs. By using the term mass culture of music, I refer to the convergence and collaboration of media practices of drama, gramophone, cinema, and print, which created a new and much-expanded public for film songs in south India. This phenomenon was not entirely unique to south India but was part of the global encounter between traditional cultural forms and the emergence of mass media during the twentieth century. Particularly during the interwar years, the shift from live performance to new media practices of music incited much debate, criticism, and celebration the world over. ${ }^{2}$

In tracing the changing relationships among Tamil drama, gramophone, and the beginnings of Tamil cinema, I argue that the music recording industry not only transformed Tamil drama music into a commodity for mass circulation before the advent of talkies but also mediated the musical relationship between Tamil drama and cinema and helped to create film songs as a new and distinct popular music genre. In the decade preceding the first Tamil films of the early 1930s, the gramophone industry catered to a rapidly growing commercial market for recorded music. The growth of the gramophone industry reorganized the entire field of popular Tamil music through mass production and circulation (Hughes 2002). From the 1920s, drama songs and star actor-singers figured prominently as some of the most popular south Indian gramophone recordings. The mass production of popular music during the late 1920s fed directly into the success of Indian sound cinema in the 1930s. The south Indian music recording industry not only helped to mediate the transition from musical drama to Tamil cinema but also was part of a commercial and cultural nexus that established film songs as India's most enduring and pervasive form of popular music in the twentieth century.

\section{A New Spin on Tamil Stage Music}

The gramophone recording industry embraced the music, musicians, and vocalists of the Tamil stage beginning in the early 1910s as part of their efforts to expand their market into south India. At first, this music only accounted for a small part of all Tamil recordings. By the 1920s, however, although films were still silent, record companies had established Tamil drama music as some of their best-selling records and transformed stage singers and musicians into recording stars. This section explores the early relationship between the gramophone industry and musical drama. It is impossible to cover the complicated

\footnotetext{
${ }^{2}$ On this point, I am referring to some excellent recent literature on how the rise of mass media reconfigurated the cultural politics of music during the interwar years. Most famously, there is the work of Benjamin, Brecht, and Adorno, who pondered and tried to theorize the emergence of mass culture in Germany. But elsewhere, there is growing interest in the encounter between new media and tradition during this same period. For example, see Walter Armbrust (1996) on Egypt. For Shanghai and China generally, see Yingjin Zhang (1999), Leo Ou-Fan Lee (1999), and Andrew F. Jones (2001).
} 
history of either the gramophone industry in India or Indian drama in this space; therefore, the focus here is on the place of music in Indian drama and its reproduction by gramophone companies and the way this relationship both prefigured and coincided with the beginnings of Tamil cinema. ${ }^{3}$

Before proceeding, it is important to specify exactly what I mean when I refer to drama music in south India. It cannot be characterized as a stable, discrete entity or a fixed tradition. Rather, drama songs were a constantly changing, highly cosmopolitan, and diversified mix. During the early part of the twentieth century, the distinct and overlapping music practices of performance and patronage in south India exposed drama music to borrowing, displacement, migration, and constant interchange. Under this proviso, the drama music to which I refer can be traced to a specific cosmopolitan Indian dramatic form of the late nineteenth century that was quite distinct in style from other regional folk dramas. Parsi drama companies started up in Bombay during the 1850s and innovated a new operatic style of performance using a proscenium stage, elaborate stagecraft, and extravagant Persian and Arabian style costumes (Khanna 1927). By the late nineteenth century, Parsi theater had emerged as a distinct school of drama in the important urban centers throughout India. ${ }^{4}$ As Kathryn Hansen argues, these highly portable and permeable theatrical activities created the "connective tissue of images, tastes, and values that underlie the success of [Indian] mass media in the twentieth century" $(2000,4)$.

In south India, professional drama companies from the north performing in Marathi, Kannada, Telugu, and Hindustani started visiting the larger cities of Madras Presidency on a regular basis in the 1870s. Inspired by these touring companies, new Tamil drama companies had begun to perform by the 1890s (Sambanda Muthaliyar 1932). The common repertoire for these Parsi-style Tamil dramas consisted of love or miracle dramas adapted from well-known Persian stories (Kulebakavali, Allavudin, Indra Saba), Hindu epics (Ramayanam, Mahabaratam, Valli Tirumanam), Tamil epics (Kovalan), Tamil folk stories (Sarangatharam, Pavalakkodi, Nalla Thangal), and stories about the lives of great Tamil devotees and saints (Nandanar, Sakkubai, Arunagirinathar). The most important dramatist during this period was T. T. Sankaradas Suvamikal (1867-1922), whose compositions established the canon for Tamil musical drama and whose drama companies launched several generations of the most important drama artistes of the twentieth century. ${ }^{5}$

Tamil professional dramas consisted primarily of a series of songs that showcased the singing abilities of the performers (Shanmugam 1978, 63-76).

\footnotetext{
${ }^{3}$ For general accounts of the history of the gramophone in India, see G. N. Joshi $(1980,1988)$ and Michael Kinnear (1994).

${ }^{4}$ For general accounts of what is usually referred to as company drama, see R. K. Yajnik (1933), Anuradha Kapur (1993), and Kathryn Hansen (1992).

${ }^{5}$ For a collection of testimonials from leading cultural figures, politicians, and religious leaders, see the commemorative volume edited by Shanmugam (1967).
} 
In south India, the stage music of the early twentieth century was a locally adapted mix of Karnatic music, Hindustani ragas, Parsi drama music, and Maharastrian bhavgeet influences that combined to create a cosmopolitan, uncomplicated, and accessible music (Ranga Rao 1986, 39). Compared to later film music, instrumental arrangements were rather sparse. They consisted of a harmonium in the lead accompanied by percussion (usually the tabla or cymbals) and, at times, a violin. Originally, the musicians were placed on one side of the stage behind a screen, but as the musicians gained more notoriety, it became customary to place the harmonium player on stage in full view of the audience. The most famous of the harmonium players, most of whom were also accomplished vocalists (pin paddu) as well, were often placed center stage as the key figures around which the performance revolved. ${ }^{6}$

The plays contained very little prose or dialogue between songs, and what little there was consisted of a few lines that either introduced or elaborated the theme of the song (Shanmugam 1972). There were standard songs for all occasions-for dedication to the gods, for every turn of plot, and an entrance and exit song for every important character (Srinivasan 1962). A contemporary literary scholar describes the inevitable role of music in these dramas: "And of course, there cannot be any drama without music ... Our professional troupes do not distinguish between dramas and operas. As the theme and story were well known, no one cared about the form and the more music, in the play, the better it was appreciated" (Myleru 1934, 71-72). In the same account, the author describes an interactive demand for songs from the audience, which seems to have frequently intervened in professional drama performances:

It is not unusual for people in the gallery — or floor - to be more correctto shout to the hero or heroine, asking them to sing some particular song, which would have no connection to the play, or the context. The request must be immediately complied with, failure to do which, would result in pelting of stones kept ready for the purpose, and raising a loud hue and cry which would make it impossible for the play to proceed. If the actor and the theatre-manager are plucky-which is very rare-they would call in the aid of the police, who would have to clear out the people by baton charges ... The words spoken from the stage are generally so inaudible and meaningless, that they do not want to hear them, and ask only for songs and more songs. The theatre serves the purpose of the music hall also for these people. (Myleru 1934, 75)

Professional drama companies constructed their entertainment appeal around songs and star singers performed for demanding audiences and created the most popular forms of commercial entertainment in the cities and towns of

\footnotetext{
${ }^{6}$ Examples include Harmonia Chakravarty Gramophone Plate K. S. Devudu Iyer, Uraiyur Harmonium T. M. Kather Batcha Sayabu, and S. G. Kasi Iyer.
} 
south India. By the 1920s, professional Tamil drama companies and drama halls proliferated throughout the districts and provided the most widely available commercial musical entertainment (Baskaran 1981, 21-61).

The rising popularity and availability of professional drama coincided with what I have elsewhere called the "music boom" in south India during the late 1920s and early 1930s (Hughes 2002). The music of the Tamil stage was a prominent component of what contemporaries considered a music boom, that is, a sudden, historically unprecedented "dissemination of music among the people." Greater availability, increased output, lower prices, better recording techniques, an expanding variety of Indian music recordings, print media, and public broadcasting all contributed to a sudden mass market and new public sphere for Tamil music. During the period of rapid growth in the gramophone business during the 1920s, some of the best-selling music was that popularized by professional drama companies. Well-known drama songs were included in HMV's south India record releases from about 1910 onward, but they were only one musical genre among others offered. ${ }^{8}$ However, beginning in the late 1910s, recorded stage songs began to make up an increasing share of HMV music selections. This trend continued throughout the 1920s until, coinciding with the music boom, drama artists emerged as the best-selling recording stars at the end of the decade. ${ }^{9}$ Seeking to exploit the already proven popularity of certain Tamil drama artists and their famous songs, the south Indian music recording industry developed a sizable drama repertoire and refashioned Tamil drama artists into a new generation of gramophone singing stars (see figure 1).

Even as record companies drew heavily on Tamil drama materials and performers, they had to be modified to fit the constraints of the new medium. The recording process abstracted, reified, and isolated the voice of the singer and the supporting music as pure musicality and produced it as a salable commodity for an emerging mass culture of Tamil music. In this way, the musical content of the drama was detached from its live performance context, scenic effects, and elaborate costumes. The limitation of roughly three and a half or four minutes of one record plate substantially shortened recordings from their original, much more lengthy stage versions, in which songs could be elaborated for as long as a half hour. For the purposes of recording, therefore, drama songs

\footnotetext{
${ }^{7}$ From a letter to the editor signed by Ganapriya in The Hindu, Sunday, August 19, 1934. The term music boom is found in numerous writings from the period, but it is probably best explained in Margaret Cousins (1935), who extensively covers her own twenty-year experience of the music scene in south India.

${ }^{8}$ For example, P. Manickam Pillai (later known by the title of Raja) was one of the first dramatists to become a gramophone artist as early as 1911. He went on to record regularly in the 1930s as part of a performance career that spanned five decades.

${ }^{9}$ This claim is based on a broad survey of south Indian gramophone record catalogues and other promotional materials covering the period in question.
} 


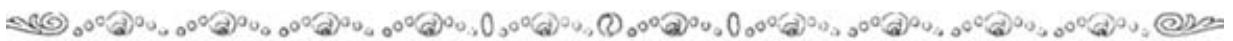

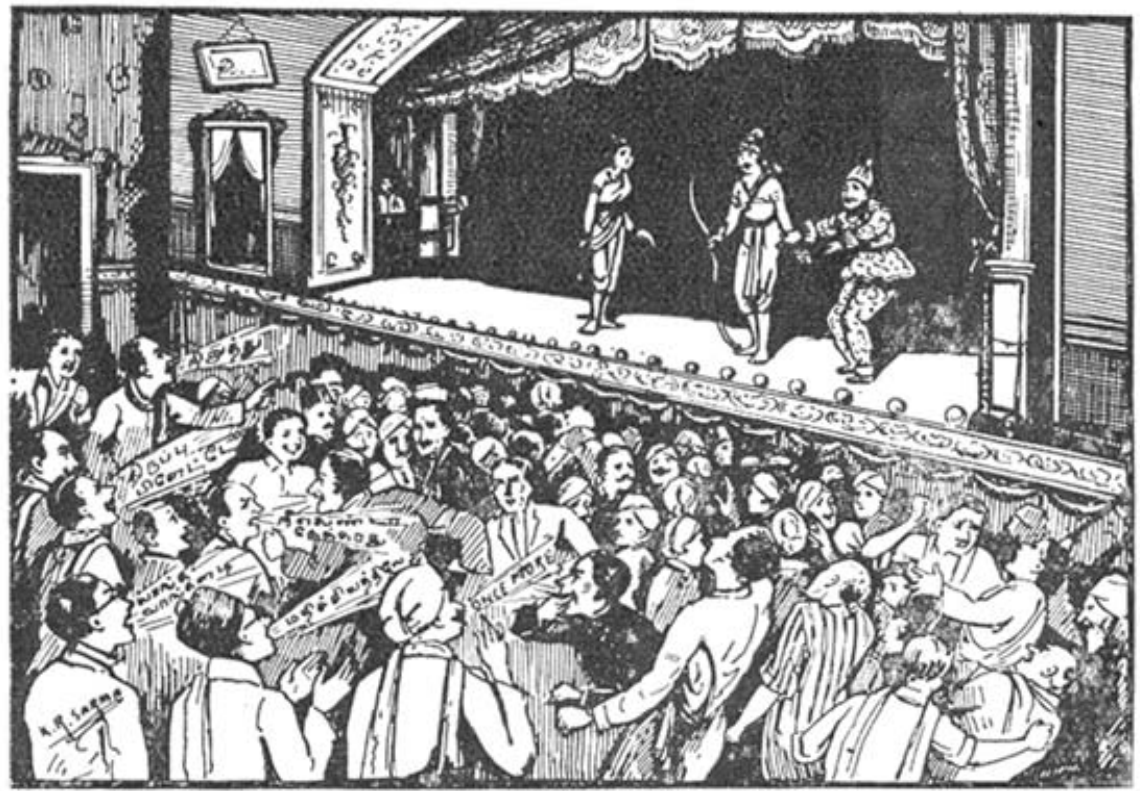

RECORD NO. C A. 713

PRICE RS. 2/12

\section{WHO WANTS TO LAUGH?}

\section{- HEAR THIS RECORD!}

Latter day developments in

South Indian Tamil Stage

are faithfully recorded here.

\section{BUY A RECORD AND ENJOY.}

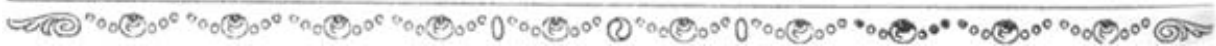

Figure 1. This record advertisement comically depicts a typical performance of a Tamil stage drama, during which an interactive crowd makes competing musical demands for songs to be repeated, stopped, sung with more feeling, and the like. Source: Saraswati Stores, Odeon Record Catalogue, August 1934 (author's personal collection). 
had to be condensed and abbreviated into versions that, through mass production and circulation, soon became the new, standardized renditions.

Gramophone companies singled out individual singers, comedians, and harmonium players from professional drama companies and selected their most popular songs for recording. The most popular gramophone singing stars of the late 1920s and early 1930s-K. B. Sundarambal, S. G. Kittappa, S. V. Subbiah Bhagavathar, and N. S. (Buffoon) Shanmugam-all started out and continued as professional stage artists. ${ }^{10}$ For south Indian audiences, these stars seem to have been better known and more popular than any of the Hollywood or Indian silent film stars at the time. A 1933 advertisement for Twin Record Company (a subsidiary of HMV that produced records at its factory in Calcutta), for example, promoted one of their Tamil recording stars as a household name in music: "In South India there is not even an infant who does not know S. V. Subbiah Bhagavathar. It is said that even the villager who cannot write their name knows of Subbiah.” Though this claim was certainly overstated as a kind of advertising effect, it nonetheless conveys a sense of the superstar status that Tamil drama vocalists acquired during the music boom.

Gramophone recordings promoted a star system of drama artists, bringing a new kind of prestige and fame that had not previously been possible for those in the profession. "Gramophone fame," as it was referred to at the time, was achieved, in part, through a concerted publicity and marketing campaign on behalf of the record companies. For example, gramophone artists figured prominently and widely in the print media. Advertised and featured in the popular press, pictures of new Tamil singing stars were reproduced in numerous publications, including songbooks, newspapers, journals, and posters. Suddenly, beginning in the late 1920s, photographs of gramophone recording artists were featured in the Tamil print media, which was then experimenting with extensive illustrated and pictorial formats for commercial publications. ${ }^{11}$ The reproduced print images helped to transform stage performers into a new kind of gramophone recording stars with greatly expanded audiences outside the face-toface relationship of a live performance.

From the late 1920s on, there was considerable competition to sign the best and most popular drama artists to exclusive recording contracts. As established dramatists were rapidly committed to recording contracts, the record companies were forced to scour south India for new and unknown talent whom they could transform into recording stars. Many aspiring vocalists and musicians were attracted to the opportunity of recording, which offered not only income but

\footnotetext{
${ }^{10}$ For biographical accounts of Sundarambal and Kittappa, see P. Chozhanadan (2002) and Akkoor Ananthachari (1938).

${ }^{11}$ One can still find collectors in south India who highly value portraits of the recording artists during this period, even though their recorded music is no longer in public circulation.
} 
also a chance to establish an immediate reputation. Recording contracts suddenly made obscure artists into widely known performers. Drama artists became associated with certain record labels and sometimes even added their gramophone company affiliation as a kind of publicity title for their name. ${ }^{12}$ In this way, not only did gramophone fame work to promote drama performers, but also recording artists served as a singing advertisement for record companies when they performed on stage.

As Indian silent cinema ignored musical drama-and before Tamil drama music and musicians joined the cinema-the gramophone recording industry transformed drama songs into a mass-produced, standardized, and widely circulated musical commodity. The gramophone industry created a new mass market and popularity for drama music as a commercial product and star system of singing and musical stars. The booming business in Tamil popular music relied, in part, on this extremely successful collaboration between Tamil dramatists and the record companies. This partnership was the first link in the creation of a mass culture of music, which helped set the stage, so to speak, for the creation of Tamil cinema as a musical form of entertainment. With sound technology of its own, Tamil cinema picked up on, joined in, and remediated drama music as film songs in the early 1930s.

\section{A Musical Revolution in Cinema Sound}

While south Indian gramophone companies forged a successful partnership with drama performers, the technology of sound was also used to create Tamil cinema as another medium of popular music in the early 1930s. In the midst of rapidly changing popular music practices in south India, sound cinema made its own musical intervention. All of the first sound films in all languages, which debuted in the cinema halls of south India, prominently featured songs. Music marked the innovation of cinema sound. It started with films based on Broadway musicals, such as The Melody of Love (Universal), The Jazz Singer (Warner Brothers), and Showboat (Universal), in 1929. These musicals were quickly followed by the first Indian talkies-Alam Ara (in Hindustani), Kalidas (in Tamil), and Bhakta Prahalada (in Telugu)_all produced as musicals by Imperial Films in Bombay during 1931. Thus, while the music boom was establishing gramophone recordings as a dominant form of popular Tamil music, the Indian sound film industry created Tamil cinema as a musical form of entertainment.

The "coming of sound" to cinema in south India should be conceived as roughly the five-year period up to 1935, when sound films finally replaced

\footnotetext{
${ }^{12}$ For example, Madurai Gramophone Plate Bafoon Shanmugam (comic actor-singer), Plate Venkataramier, Gramophone Fame Ernankulam K. V. Naidu (tabla), Odeon T. S. Krishna Iyengar (vocalist), and HMV Visaloor Subramania Iyer (vocalist).
} 
silent films and film songs replaced live musical performances in the cinema halls of south India. Though the production of Indian silent films dropped off steadily from about 300 in 1931 to only 7 in 1935, both silent and sound films continued to be produced and screened side by side during the period from 1930 to 1935. Initially, Tamil sound film production was insufficient to provide a steady schedule of films for any given exhibition venue, and the supply of Tamil talkies at most cinema halls was sporadic until about 1935. Over the first three years of sound production in south Indian languages, only twenty sound films were produced (twelve in Tamil and eight in Telugu) compared to sixty-eight silent films produced in south India over the same period. This meager supply of talkie films was even further diminished by problems with sound synchronization and clarity, which effectively limited their circulation. Furthermore, it took at least five years for the majority of cinema halls to invest in the rewiring required to convert to cinema sound. Thus, the coming of sound cinema in south India was neither immediately triumphant nor a discrete rupture in film practices.

Though it took several years to establish the new technology, the introduction of sound radically altered the Indian film industry and its role in the global exchange of motion pictures. ${ }^{13}$ Not only did Indian sound films replace silent films, but also they eventually helped to reorganize the film industry in India away from the dominance of imported feature films. Until 1928, when sound was introduced, 95 percent of all films shown in India were foreign imports (Government of India 1928). Over the course of the 1930s, however, sound technology helped the domestic film industry expand rapidly through the production of Indian films in Indian languages. While the production of Indian talkies increased from 27 to 233 between 1931 and 1935, the import of foreign films dwindled, so that by the end of the decade, they attracted only limited and relatively elite audiences of Europeans, English-educated Indians, and Anglo-Indians. Thus, cinema sound decisively shifted the balance in favor of the emergent Indian film industry and fostered a proliferation of regional-language-based cinemas throughout the country. ${ }^{14}$ For Indian film productions, sound was a decisive advantage over the foreign competition and created new opportunities to market cinema to Indians.

As part of the effort to create a specific linguistic and regional appeal through sound for local audiences, film songs and music presented new ways of conceiving cinema. N. R. Desai, a film distributor in south India during the 1930s, explains, "With the coming of the talkies the Indian motion picture

\footnotetext{
${ }^{13}$ For a wider discussion of how cinema sound changed the global trafficking in films, see Douglas Gomery (1980) and A. Williams (1992).

${ }^{14}$ This proliferation of linguistically specific cinemas within the category of Indian cinema is unique among world cinemas. As a national cinema, there is no other that can match the range and volume of linguistic and regional diversity that constitutes Indian cinema.
} 
came into its own as a definite piece of creation. This was achieved by music ... it gives us musical entertainment which even the best Hollywood pictures cannot" (quoted in Garga 1996, 80). There was an immediate and broad consensus within the Indian film industry that music had redefined the cinematic medium. Even before talkies replaced Indian silent films, music marked the transition to sound cinema. In the words of one Indian film critic, "Music is the essence of a talking picture" (Sawhney 1933). Initially created as a form of opera, early Tamil films contained as many as fifty or sixty songs within a standard running time of about three hours, and songs made up as much as four-fifths of any given film scenario. One film critic described the three-year history of Tamil cinema to 1934 as a continuing effort toward perfecting musical cinema, announcing that "the Tamil Talkie is day by day advancing towards the musical is a well known fact to the theatre-going public on Tamil Nad" (Funny Magazine 1934). The dominant position of film songs in Indian cinema was such that another early south Indian film reviewer suggested in 1933 that it would be more correct to call them "singing films" rather than “talking films" (Nagara Rao 1933). This reviewer’s suggested name, "singies" (rather than talkies) never caught on, but nonetheless conveys the initial centrality that film songs occupied in the conception of early Tamil cinema.

One early Tamil film music director boldly proclaimed in a Madras film journal, "Everybody knows that Music is a Universal language. Be it in any language, Music of whatever country it may be, if well sung has captured any heart anywhere in the entire world." His main example was foreign films, which had "won many hearts in spite of the language handicap" (Jayarama Aiyer 1938). Within India, music was presented as the answer to the newfound problem of linguistic diversity that sound presented to the film industry. Music, in this sense, replaced the presumed visual universality of silent films with a new aural universality. Music was believed to appeal directly and unmediated to the hearts and minds of film audiences, regardless of whether they understood the language of the film. ${ }^{15}$ Songs from the earliest Tamil films were not performed exclusively in Tamil but in a mix of many different languages depending on the song and the particular linguistic abilities of the vocalists. For example, the first Tamil film, Kalidas, produced in 1931, contained songs in Tamil, Telugu, and Hindustani. The appeal of these first films was not so much conceived around the linguistic specificity of Tamil as it was around the primacy of the music. Tamil films throughout the 1930s featured a surprising abundance of songs in languages such as Telugu, Sanskrit, Hindustani, and Bengali, which could not be understood by the majority of Tamil audiences. It seems that Tamil film producers had faith that the universal appeal of music could overcome linguistic differences and perhaps even attract wider audiences.

\footnotetext{
${ }^{15}$ On the presumed visual universality of silent cinema, see Miriam Hansen (1985).
} 
Sound allowed Indian film producers to exploit musically based drama traditions in ways that had been beyond the reach of Indian silent cinema. With the added dimension of sound, Tamil film producers, like the gramophone companies before them, turned to well-known drama sources. Following the conventions of the Tamil stage, every Tamil film until November 1935 (the first fifty or so) had a mythological theme based on Hindu and Tamil epics about the exploits of the gods or great devotees. ${ }^{16}$ The vast majority of all Tamil films during the 1930s, more than 200 in total, were based on earlier stage dramas and reworked for a three-hour film format. In many cases, drama companies would be hired to perform their already popular stage productions in front of a relatively immobile camera. The musical arrangements for the earliest Tamil films included the same harmonium-led ensemble with percussion, which was the mainstay of the Tamil stage. ${ }^{17}$ All accounts suggest that these early film producers tended to stick "very tenaciously to the ubiquitous harmonium (or American Organ)." 18 The south Indian singing stars and musicians of the stage brought their repertoires, singing styles, and musical accompaniments to the cinema, but they did so under the new constraints of film production.

Early Tamil cinema aligned itself with the gramophone trade in privileging, exploiting, and promoting the music and singers of the stage. More than just sharing Tamil drama as a common referent with Tamil cinema, the record companies prepared the way for Tamil cinema to follow. In particular, the gramophone companies' recruitment and exploitation of drama music and artists provided an immediate example for the emergent Tamil film industry. Thus, early Tamil cinema productions tried to capitalize on the newfound popularity of recording stars by recruiting them to perform in their films. In many cases, a drama artist's previous gramophone recordings were prominently featured in prerelease advertising for Tamil films. Perhaps more important than any previous notoriety they had gained on the stage, successful gramophone recordings helped drama artists move into Tamil cinema. For Tamil drama artists, gramophone recordings were often the first step toward becoming film performers. This is easily confirmed by comparing the names included in south Indian

\footnotetext{
${ }^{16}$ On this point, Ashok Renade (1980) rejects Barnouw and Krishnaswamy's (1980) account, suggesting that the real causes of the abundance of music in Indian cinema can only be found in their mythological content. He claims that because early Indian cinema was almost exclusively mythological and because these stories have always been expressed musically, the dominance of song is almost automatic in Indian cinema. There is certainly a connection between mythological stories and musical expression. However, Renade's formulation merely extends Barnouw and Krishnaswamy's logic by replacing drama with Hindu mythology as an essentialized Indian musical continuity.

${ }^{17}$ Unfortunately, the first Tamil films of the early 1930s no longer exist, and Tamil film songs were not recorded commercially before 1935, so we do not have direct access to these productions. In order to study this period, we are forced to rely on contemporary descriptions, reviews, and criticism.

${ }^{18}$ Printed anonymously under the name "Musical Director" (1933).
} 
gramophone catalogues with the actor-singers who performed in early Tamil cinema. It is evident that most of the early actor-singers, including the most famous in Tamil cinema, had previously recorded gramophone plates. ${ }^{19}$ In this respect, Tamil cinema appropriated the drama vocalist star system that south Indian gramophone companies had already promoted.

During the early 1930s, Tamil gramophone and cinema came together around popular stage drama to form the cornerstone of the emergent mass culture of music. The emergence of a musically oriented Tamil cinema added to and eventually grew beyond the relationship between gramophone and drama. Yet it was this specific historical convergence of live performance traditions of the professional Tamil stage with two new mass media and their complicated and changing relationships that created the conditions for a dominant new mass culture of music in south India.

\section{Recording Tamil Dramas for Gramophone and Cinema}

This section traces the relationship between south Indian gramophone companies and the beginnings of Tamil cinema, highlighting the ways in which music recordings mediated the appropriation of Tamil drama music for the purposes of cinema. With the centrality of music firmly established, the early Tamil cinema converged and coincided with the sudden and widespread success of south Indian record companies during the early 1930s. While Tamil cinema producers were trying to work out their own musical entertainment, the gramophone companies had already established a new market and high public profile for their music products and singing stars. Thus, in many ways, the gramophone industry served as an example and a resource for the emergent Tamil film industry as it created its own music-based entertainment. Throughout the decade, the emergent south Indian film and music recording industries became linked through their mutual exploitation of the same Tamil drama music and vocalists and though their collaboration in the production and promotion of film songs and vocalists. This new alliance around film songs brought the cinema and recording industries together in a powerful partnership that is still going strong today.

\footnotetext{
${ }^{19}$ A review of south Indian gramophone catalogues from the late 1920 s and early 1930 s reveals a consistent pattern of music recording preceding entry into Tamil cinema. For example, the Saraswati Bai sisters recorded for HMV in July 1927; P. Rukmani for HMV in 1927; Miss M. S. Subbulakshmi of Madura for HMV in January 1930; Serukalatur Sama for Columbia in December 1931; M. M. Dandapani Desikar for Columbia in December 1931; Kotamangalam Seenu (V. S. Srinivasan) for Odeon in 1933; S. S. Main Iyer for Columbia in December 1931; N. S. Krishnan for Odeon in 1932; K. Aswathamma for Odeon in July 1933; and M. Saradambal of the Golden Company for Odeon in July 1933, to name but a few notables who recorded gramophone plates before moving into Tamil cinema.
} 
During their first thirty years in India, the gramophone and cinema industries had no direct association beyond the fact that gramophone records were sometimes played as audible accompaniments during silent cinema shows. Although some enterprising film exhibitors experimented with using the two media to complement each other, the gramophone and cinema businesses each developed their own specialized and separate markets. After the advent of Indian sound cinema, this separation broke down, and the two media began to overlap in their use of drama musicians and music. Yet during the early 1930s, there was very little direct involvement between south Indian record companies and Tamil film productions. Indeed, judging from south Indian record catalogues and advertisements from the period, there were very few Tamil film song records on the market before 1935. Excluding Columbia's recordings of actress T. P. Rajalakshmi singing drama songs from the first Tamil talkie, Kalidas, in 1931, film songs were not explicitly marketed by gramophone companies until about 1935. During these first years, gramophone companies offered drama songs and record sets as a kind of surrogate film music running parallel to stage performances and cinema hall exhibitions (see figure 2).

Rather than through the recording of film songs, south Indian gramophone companies and film productions first came together around their mutual reliance on Tamil drama reproductions. Tamil cinema extended the commercial exploitation of drama performers, stories, and music that had been started by the gramophone companies. Tamil drama not only provided a shared musical resource for both records and films but also helped bring the two media industries together. During the early 1930s, there was even a kind of competition between the south Indian record companies and Tamil film productions, as both offered reproductions of the same Tamil dramas. As most Tamil films produced during the 1930s appropriated already established music, performers, and songs of the stage, they followed and even encroached on the success of the south Indian recording industry. As if in response to the emergence of Tamil cinema, the record companies took a further step in their exploitation of stage dramas by introducing their own full-length drama record sets.

All south Indian gramophone companies experimented with their own studio recordings of abbreviated dramas performed by their own troupe of drama artists. Saraswati Stores was the first to established its own dramatic company for the production and promotion of drama record sets in July 1933 (see figure 3). When Saraswati Stores released its first drama record set, Kovalan, in May 1934, the music critic for The Hindu newspaper announced that the gramophone business had reached a new stage in its development (see figure 4 ):

South Indian gramophone literature seems to be passing through its second stage of growth. At first, we had individual records, covering 


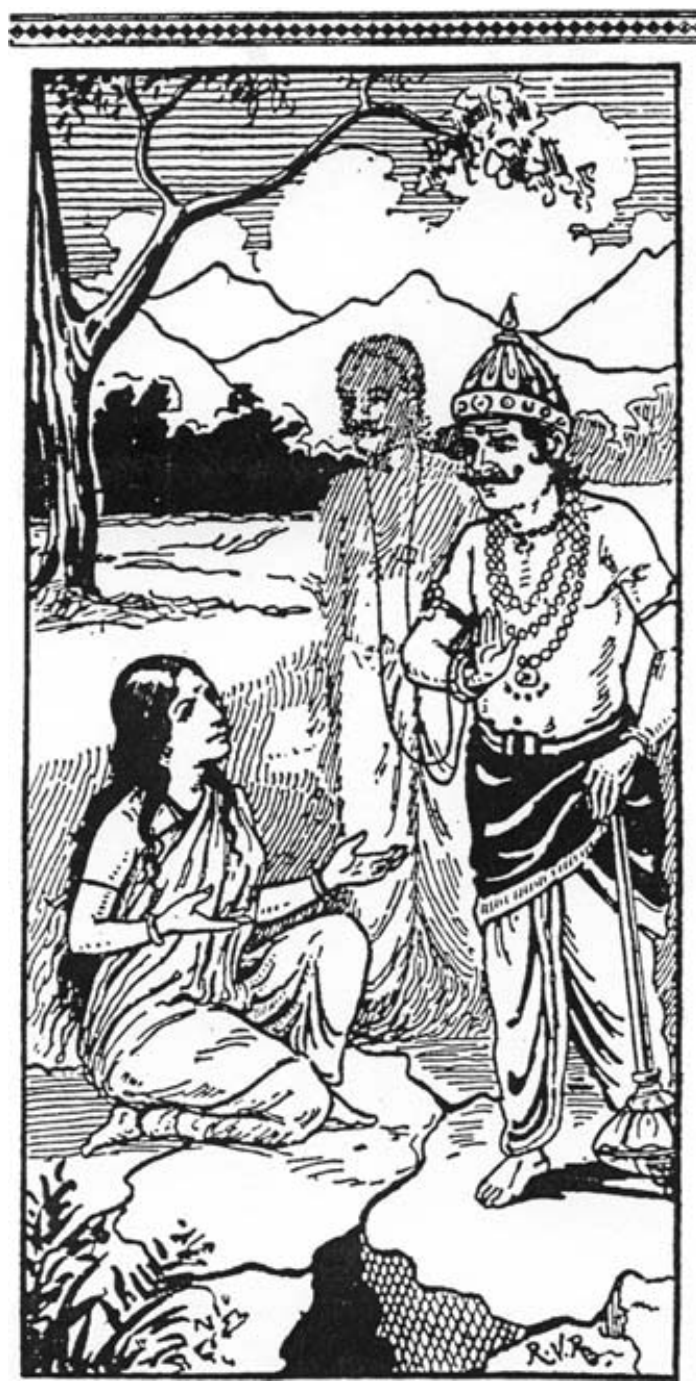

\title{
Scenes from the Stage
}

\author{
Recorded and Released \\ for the first time to the \\ Gramophone Audience.
}

\section{Savitri Satyavan}

\section{Record No. C. A. 598}

is a musical duet dealing with the episode where Savitri begs the life of Satyavan from Yama the Lord of Death. The parts are well sustained by the well-known and popular artistes V. S. Srinivasan and P. S. Krishnaveni.

Figure 2. A record advertisement for a duet from a well-known "mythological" drama that was also released as a Tamil film, Savitri (Madan Theatres, Calcutta, 1933). Source: The Hindu, July 12, 1933, 19.

one side or two. Later on, the music and sometimes the talk of more than just one artiste in the shape of a duet or dialogue were recorded. And now a story or an episode by itself forms the subject of a set of gramophone records. ${ }^{20}$

A drama that generally ran four to five hours on the stage was performed in its entirety on ten records in a playing time of about one hour (see figure 5). All of

${ }^{20}$ Signed "C. R. S." (May 5, 1934). The author, C. R. Srinivasa Iyengar, was the music critic for The Hindu during the early 1930s. 




\section{SARASWATHI STORES DRAMATIC PARTY.}

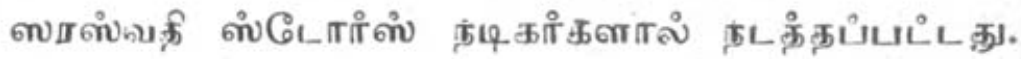

TAMIL.

VOCAL.

Фक्षழ़े.

C. 721
-730 $\left\{\begin{array}{l}\text { Kovalan Drama } \\ \text { கோவலன் ட்ராமா }\end{array}\right.$

20 Parts.

20 பாகங்/கள்.

A Set of 10 records in a Metal Box.

\section{SPECIAL PRICE RS. 25.}

20 பாகங்கள் அடங்கிய பெ பெட்டியுடன் ஸ்பெவில் இீல ந5. 25.

Figure 3. Inside front cover, Saraswati Stores, Odeon Record Catalogue, May 1934 (author's personal collection). 


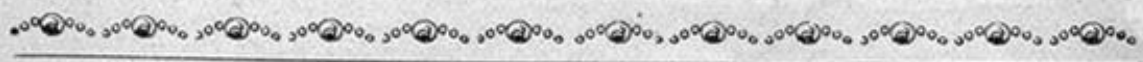

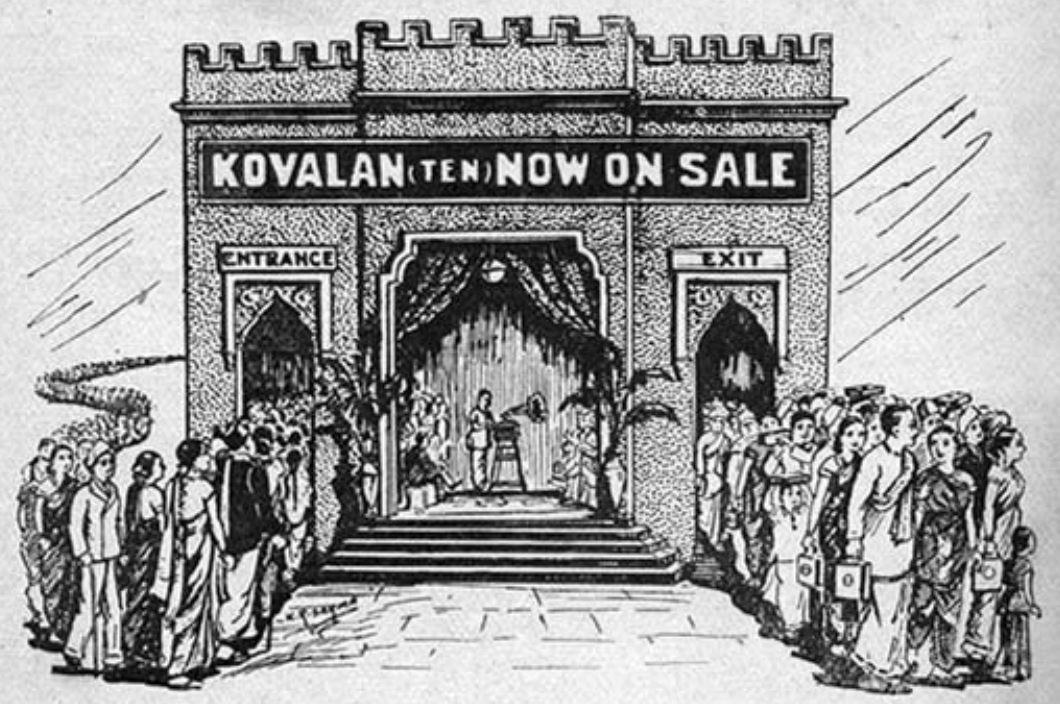

STILL GOING STRONG

THE DEMAND FOR

\section{KOVALAN TEN}

continues with added vigour and every day brings fresh crowds to hear this masterpiece.

\section{HEARD IT YET?}



Figure 4. An advertisement for Kovalan, Saraswati Stores' first drama record set. Source: Saraswati Stores, Odeon Record Catalogue, June 1934 (author's personal collection). [Located with page 14] 


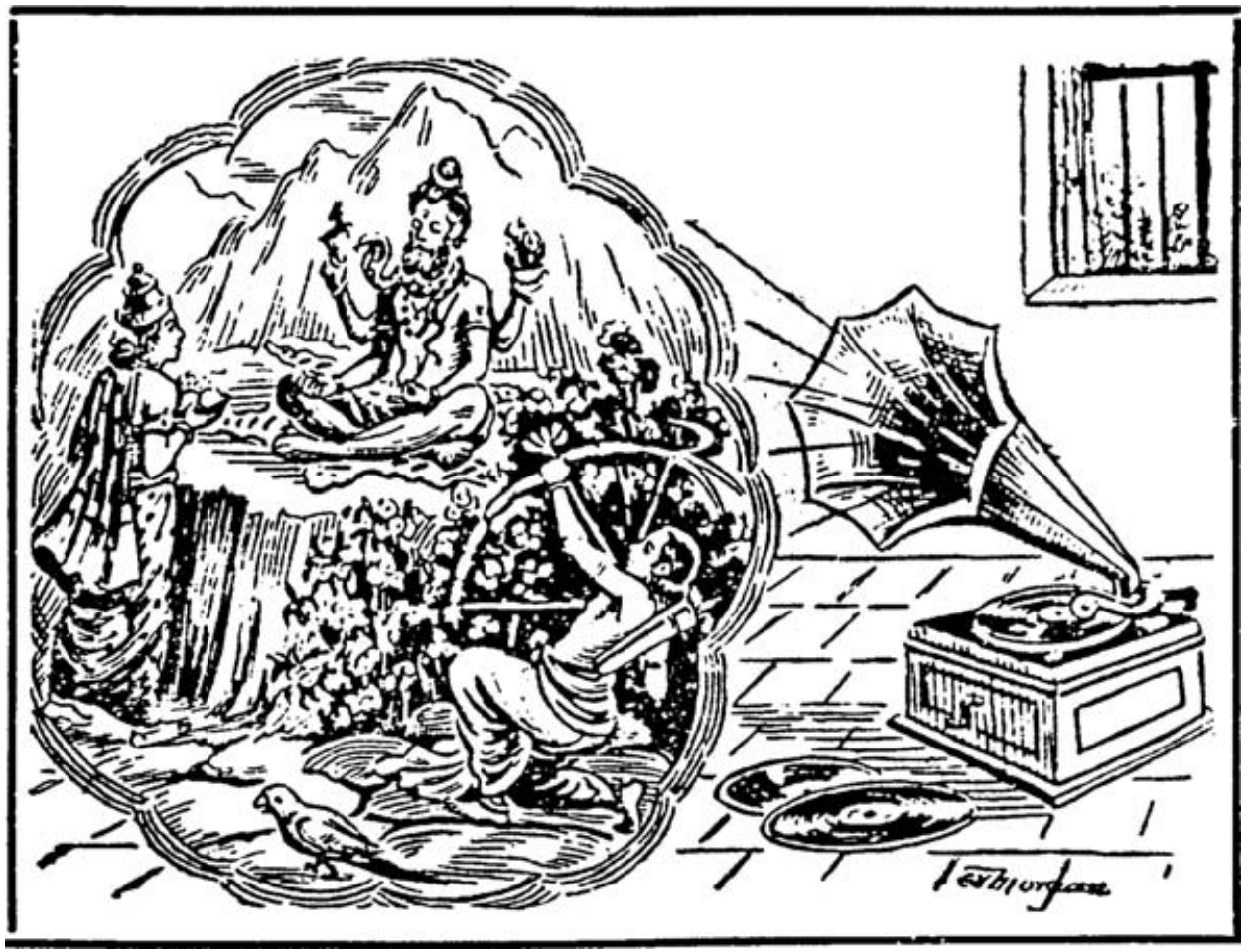

Figure 5. This image accompanied a gramophone record review in a weekly arts criticism feature, aadal paadal (Song and Dance), written by Kalki R. Krishnamurthy and published by the leading Tamil variety magazine. Source: Ananda Vikatan, May 20 1934, 28.

the other gramophone companies quickly responded in kind with their own drama sets, creating something of a musical fad. In a matter of months, these drama sets became the most prominently advertised of all south Indian gramophone offerings. Considering that drama sets encouraged the sale of as many as ten records at a time, the record companies appeared to be especially keen to promote this new line of musical products.

The drama sets were released in simultaneously with the early Tamil films, and each gramophone company produced the same drama stories on records that were being shown in the cinema halls. During the early 1930s, for any particular Tamil drama from the established stage repertoire, there were almost always two or three competing versions of the drama (drama songs, drama sets, and Tamil talkies) available at the same time (see figure 6). ${ }^{21}$ Drama sets were released in competition and sometimes even in collusion with Tamil film versions of the same story. These drama record sets, however, were

\footnotetext{
${ }^{21}$ For example, in 1935, both Orr's Columbia House and Saraswati Stores Odeon released record sets, coinciding with the Tamil film Dumbachari (Pioneer Film Company, Calcutta).
} 


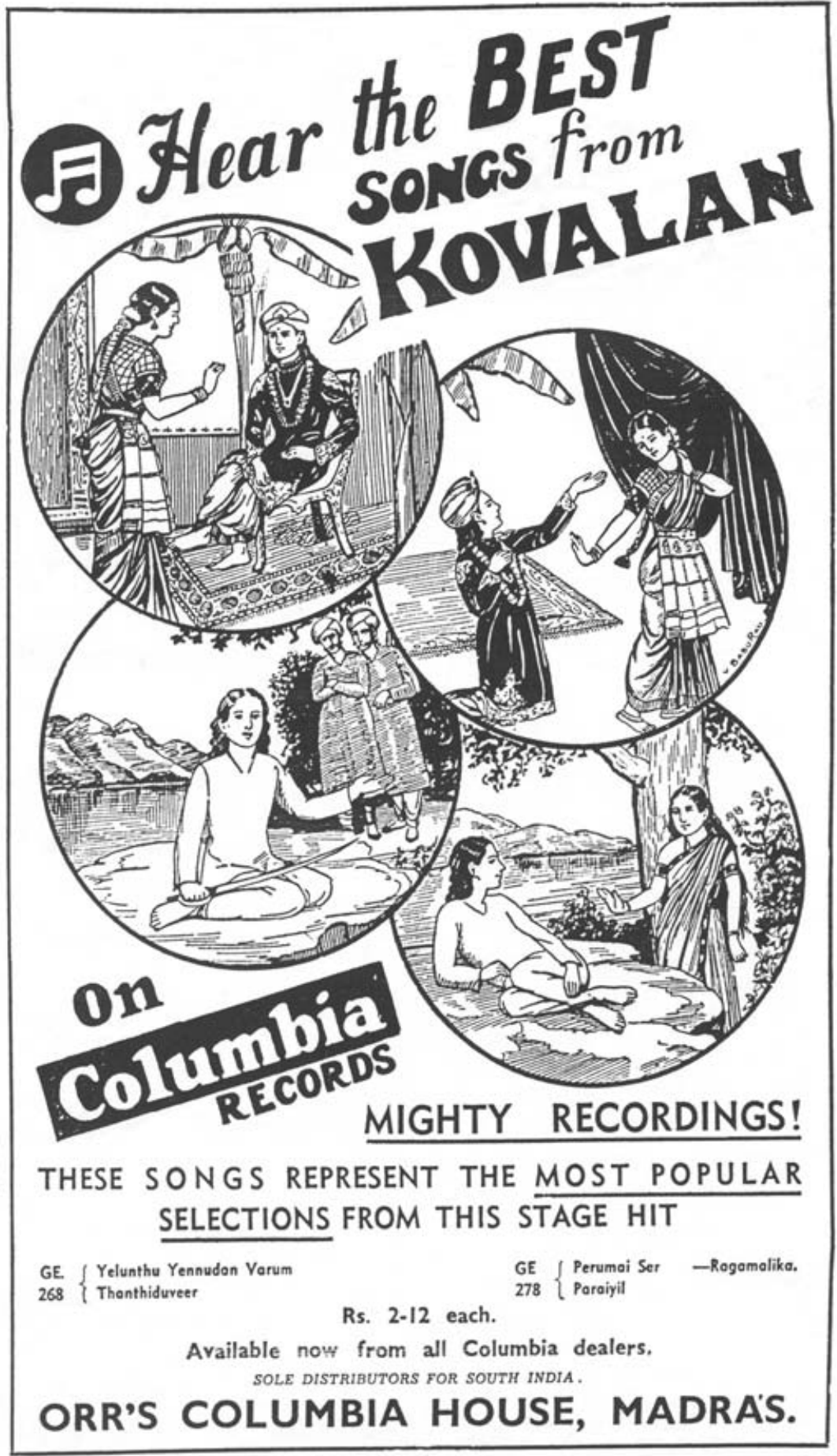

Figure 6. Orr's Columbia House advertisement for a competing production of Kovalan drama song records. Source: The Hindu, May 7, $1934,7$. 


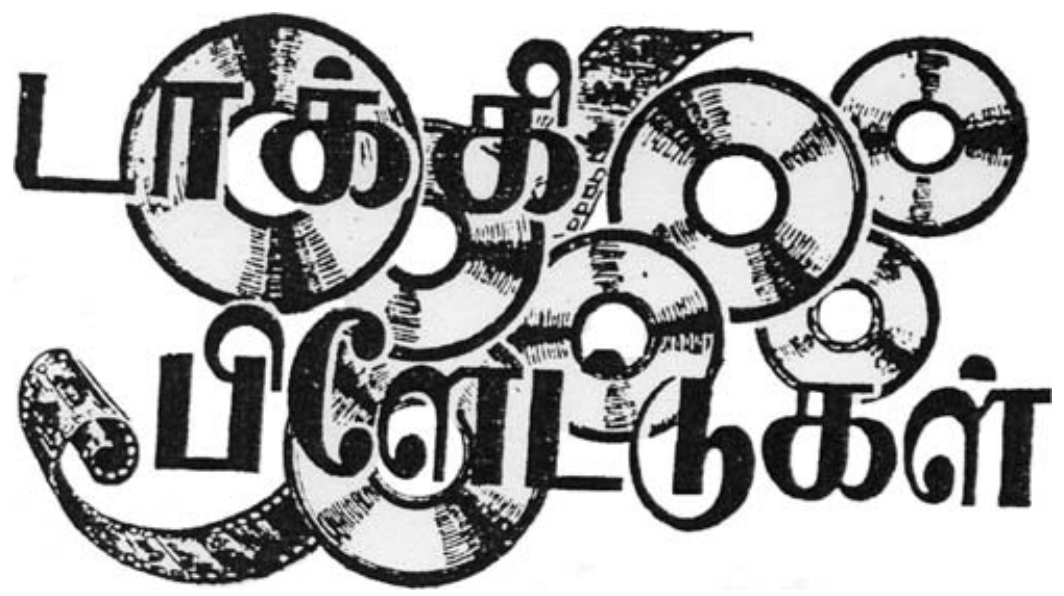

Figure 7. In Tamil, this reads "Talkie Plates." This is the headline title for a magazine review article of film song recordings, which heralds the musical partnership between the gramophone and cinema. Source: Ananda Vikatan, April 3, 1938, 38.

something of a passing fad whose heyday lasted for less than a decade. ${ }^{22}$ Their prominence as a gramophone offering diminished and was eventually replaced when Tamil film songs emerged as the best-selling popular records during the late 1930s (see Figure 7). Instead of working in competition with each other, the recording and film companies learned to work together, and they laid the commercial and institutional foundation for producing and sustaining the music of Tamil cinema, both as a filmic necessity and as an accompanying mass culture of music.

\section{Cross-Ownership and Economic Integration of Gramophone and Cinema}

Institutionally, the gramophone companies were ahead of the south Indian film industry. When Tamil film production started to shift away from Calcutta and Bombay to newly built film studios in the south during the mid-1930s, the south Indian recording companies already had a highly successful business and were in a strong position to offer their sound services for cinematic purposes. Starting in 1934, when Srinivas Cinetone's Sound City opened in Madras, the number of sound film studios in south India grew rapidly and totaled ten by 1939. These new facilities encouraged a general southward shift in the production of Tamil films, away from studios in other parts of India. By 1937, more Tamil films were being produced in the south than was elsewhere in India. As the film industry in south India quickly institutionalized a steady production of Tamil films by the mid-1930s, the south Indian record

\footnotetext{
${ }^{22}$ Drama sets continue to be recorded and marketed on a small scale, but their market presence is marginal compared to film music.
} 
companies used their already established musical talents, expertise, and capital to make their way into almost all aspects of the cinema business.

Undoubtedly, the best example of the convergence between the gramophone and Tamil cinema businesses is the career of A. V. Meiyappan. On the basis of commercial success in the gramophone trade, Meiyappan established and ran one of the most important and long-standing film studios in Madras. As one of the founding members of Saraswati Stores, the southern Indian agent of Odeon Records, Meiyappan led the move from music recording to Tamil cinema. Saraswati Stores' highly profitable record business not only funded Meiyappan's early efforts at Tamil film production but also put it among the first recording companies to produce substantial numbers of recordings that ran parallel to Tamil cinema during the late 1930s. After starting out as a young man selling gramophone records in his father's shop, Meiyappan helped launch Saraswati Stores in collaboration with Odeon Records during the music boom of the late 1920s. Saraswati Stores soon emerged as one of the market leaders in south Indian records. Buoyed by his success in one medium of musical entertainment, Meiyappan branched out to another in 1935 with his Saraswati Sound Pictures' Tamil film Alli-Arjuna, produced at Pioneer Studios in Calcutta. This film production was, in part, an extension of Saraswati Stores' drama record set productions, which were still quite popular at the time. The same Saraswati Stores Drama Troupe that had already recorded numerous drama sets performed the acting, singing, and music in Alli-Arjuna, and the performers recorded a corresponding seven-plate record set, which was released about one month before the film. Although this first effort was not particularly successful, the following year, Meiyappan launched a new venture, Saraswati Talkie Producing Company, and produced a second film, Ratnavali, also at Pioneer Studios. Again, the film production was accompanied by a corresponding recording of the "filmed drama" on Odeon records for Saraswati Stores. By 1938, when Meiyappan produced his first successful Tamil film, Nandakumar, under the new banner of Pragati Pictures, drama sets were no longer being recorded and sold as such but had been replaced by the gramophone recordings of the film songs themselves. This shift in marketing reflected an emerging awareness of Tamil film music as a distinct and new musical product that was no longer equated with the stage.

Going well beyond Meiyappan’s own Tamil film productions, Saraswati Stores seized on this new recognition of film songs and aggressively began to record, produce, and market songs on the Odeon label from other film production companies beginning around 1937. The Saraswati Stores Orchestra (sometimes referred to as the Odeon Orchestra) specialized in film music, providing both song and background accompaniment for many Tamil films into the late 1940s. In most cases, when Saraswati Stores provided the music for the film production, it also recorded and released corresponding gramophone plates. This commercial overlap between gramophone and Tamil cinema interests provided a foundation 
for the establishment of AVM Film Studio in Madras in 1940. After the disruptions of the World War II, AVM Studio firmly established itself as one of the leading Tamil film producers, and Saraswati Stores was eventually subsumed within the much larger film company. To this day, AVM is one of the main film studios in Chennai and maintains its link with the recording business.

Another example of the growing partnership between record companies and Tamil cinema during the 1930s was the Madras record company Orr's Columbia House, which also used its musical resources to move into the cinema trade. Beginning in the late 1920s, Columbia Records emerged alongside HMV as one of the leading producers and dealers of south Indian recordings. Orr's Columbia House was officially established during the music boom of the early 1930s as a branch of P. Orr \& Sons, a military outfitter turned department store specializing in luxury items and services. ${ }^{23}$ As one of the leading south Indian recording companies, it expanded its musical operations into the cinema in 1935, when it opened a subsidiary concern named Orr's Gramophone and Talkies. The company's musical group, known as Orr's Columbia House Orchestra, which had previously provided music for its own studio recordings, was used to record film songs released on the Columbia label.

In addition to releasing film song gramophone recordings, the company moved into cinema distribution by securing the rights for the many successful film productions of K. Subrahmanyam's Madras United Artists Corporation. ${ }^{24}$ Orr's continued to partner with K. Subrahmanyam to provide music for and produce records of numerous Tamil films produced at his studio, Madras Picture Producer's Combine, during the late 1930s and early 1940s. Perhaps Orr's most significant contribution to Tamil cinema was its brief venture into film production. In 1938, Orr's released its first and only Tamil film, Vishnu Leela, also produced at Subrahmanyam's Madras studio. The film, which boasted twenty-seven songs, was advertised as a "musical extravaganza" and accompanied by parallel film song recordings on the Columbia label (Orr's Gramophone and Talkies 1938).

Orr's Columbia House Orchestra was also involved with many other Tamil film productions, most notably, Tukaram (produced at Central Studios, Coimbatore in 1938), a remake of a Telugu version of the Marathi devotional film hit. ${ }^{25}$

\footnotetext{
${ }^{23}$ In addition to selling gramophones, Orr's also dealt in jewellery and diamonds, offered silversmith and watch repair services, and manufactured survey equipment. Orr's was known for having introduced gas lighting to Madras, it was the first Madras-based importer of automobiles, and it was the city's leading bicycle merchant. See the Orr's commemorative volume (Orr's and Sons 1949).

${ }^{24}$ For more about the success of K. Subrahmanyam and the importance of his films, see Barnouw and Krishnaswamy (1980, 113-15). One of the authors of this account, S. Krishnaswamy, is K. Subrahmanyam's son. See also Baskaran (1996, 99-200).

${ }^{25}$ A 1938 advertisement in the film journal Muvi Heralt, Andu Malar for Columbia film song recordings listed twenty-five titles from ten different films (eight in Tamil and two in Telugu).
} 
In this film, Musiri Subramania Iyer, a famous Karnatic vocalist and Columbia recording star, starred in the title role of the Maharastrian poet-saint and recorded the inevitable gramophone plates that ensued.

In addition to Saraswati Stores and Orr's Columbia House, HMV and its subsidiary company, Twin Records, were the other main recording companies that were heavily involved in the production of gramophone records of Tamil film songs from the late 1930s onward. As for the other record companies, which had joined in the speculative rush of the music boom, most of them folded just as quickly by the mid- to late 1930s. It seems that survival in the south Indian recording business required a link with film productions. The record companies that persisted into the late 1930s-HMV, Odeon, and Columbia-effectively monopolized the first systematic exploitation of Tamil cinema song recordings. ${ }^{26}$ By the end of the decade, the Tamil film industry and the south Indian music recording business had formed a relationship of mutual support in the promotion of film songs and singers. This convergence of parallel media forms and institutions around film songs not only created a new mass culture of Tamil music but also represented a key alliance in the music-based Tamil film industry.

\section{Film Song as a New Musical Genre}

Using Tamil drama as a ready-made lexicon of songs and stars, Tamil cinema was conceived as a kind of musical entertainment. Within a few short years during the 1930s, those in the increasingly integrated film and recording industries combined musical dramas with other sources to create a new composite musical genre. This section considers what went into the creation of the distinct musical style of Tamil film songs that simultaneously incorporated and transcended drama music.

Though the musical form of Tamil cinema was inspired by musical drama styles, Tamil film songs were never entirely predetermined by the conventions of stage dramas. The creative process of setting the tunes to Tamil lyrics and arranging the instrumentation for Tamil film songs was a complicated undertaking that brought musicians and music from diverse backgrounds together in new ways. An important mitigating factor in the development of early Tamil film music was the fact that until the late 1930s, most Tamil films were

\footnotetext{
${ }^{26}$ The south Indian gramophone business became increasingly centralized during the 1940s. With the beginning of World War III, Meiyappan ended his relationship with the German-owned Odeon records, and Columbia acquired the rights to all of Odeon's south Indian cinema recordings. Only a short time later, Columbia was itself subsumed by the Ruby Record Company of Bombay, which was, in turn, acquired by the Gramophone Company in 1943. With this move, the Gramophone Company gained a virtual monopoly on the Indian recorded music market by running Columbia and Odeon as subsidiaries.
} 
produced in the film studios outside south India in Calcutta, Bombay, Kolhapur, and Pune. Within months of the release of the first Indian talkie, studios in Calcutta and Maharastra arranged for the production of Tamil and Telugu films for south Indian cinema markets. In some cases, these studios contracted someone who could arrange for Tamil dramatists to provide suitable songs and language for the film. Many early Tamil films were produced on sets that had been already used for films in other Indian languages, with north Indian studio musicians providing the background and incidental music. ${ }^{27}$ The Tamil films, which were produced in the Calcutta film studios, often included cameo appearances by well-known Bengali vocalists singing popular songs based on already successful films in other Indian languages. The production of early Tamil films in Calcutta and Maharashtra introduced a new kind of musical cosmopolitanism using styles, tunes, arrangements, and musicians that were largely unfamiliar in south India at the time. These new contexts of studio production brought a range of music with no previous connection to Tamil drama into widespread currency throughout south India.

Over a few years during the 1930s, Tamil film songs quickly developed a hybrid musical style. The early music directors of Tamil cinema started with the same musical arrangements that had been used on the stage, but they quickly diversified the typical harmonium-based sound that had become synonymous with stage music. Like Tamil musical drama, Tamil cinema drew on a wide variety of musical performers, styles, and instruments but combined them in new ways to create a more eclectic and fluid film song form. In addition to the hybrid drama sources, music directors crafted Tamil film songs from a wide range of musical derivations, including classical Indian Karnatic and Hindustani music, folk songs, devotional music, and Western musical styles (Baskaran 1991). This musical eclecticism was one of the primary means by which early Tamil film makers appealed to the diverse tastes of their imagined and untested audiences.

Variety was a key element in defining Tamil film songs as a new genre. From the outset, Tamil cinema producers used diverse musical appeals to cater to a range of musical tastes. One 1934 Tamil film review nicely narrates this point through a short retrospective on the musical development of Tamil cinema:

That the Tamil Talkie is day by day advancing towards the musical is a well-known fact to the theatre-going public of Tamil Nad ... First of all we had in Valli's Wedding [Pioneer Films, Calcutta, 1933] a kind of alluring music in the form of folk songs that catered to the masses and it was a pucca [proper] success ... The second film that attracted the public was Sita Kalyanam [1933], a high-grade picture of Prabhat, which also

\footnotetext{
${ }^{27}$ For example, the noted Bengali blind musician K. C. Dey and his party provided the background music for many of the Tamil films produced at the Calcutta studios of East India and New Theatres during the 1930s.
} 
contained songs, but not of a variety that would appeal to the pit. ... Then came the films, Lava Kusa [1934] of Tamil Nadu Talkies and the Sakunthala [1934] of Pioneer Films, which managed to improve slightly in the quality of music, especially in terms of providing a type of music that could have an all-class appeal. (Funny Magazine 1934)

This passage narrates the successes of the first four years of Tamil cinema as a series of musical experiments in which the type of music served as a marker that designated a film's class-based appeal. Tamil film producers navigated a market conceived as split between high-class and mass musical tastes. According to the reviewer just quoted, the ideal was to come up with a balanced mixture of songs that might approximate some kind of "all-class appeal." In this sense, the music of Tamil cinema operated as a kind of mode of address, articulating a kind of social hierarchy of film taste.

As much as drama served as an example for how to make Tamil films, it also served as a benchmark for judging the progress of Tamil cinema. Already in the early 1930s and increasingly throughout the decade, music directors attempted to distinguish their film songs from the conventions of stage music by experimenting with a new mix of musical styles and instruments. There was an explicit effort to avoid the harmonium-based sound of drama music and adapt innovations of Western style orchestration and light music that had earlier been experimented with on gramophone recordings (Hughes 2002). According to Margaret Cousins, an Irish feminist, theosophist, and music scholar who lived in Madras between 1915 and 1935, one of the ways in which gramophone records influenced musicians and the music-listening public in India was by bringing a new open-mindedness to the mixing of Eastern and Western music and the creation "a new ideal to the playing of Indian instruments, both singly and in combination" $(1935,70-71)$. Speculating on this new kind of Indian music, Cousins anticipated the style of orchestration that would develop into film songs during the 1930s.

Another early music director described this new kind of hybrid music in very similar terms:

The fact that emerges even from this cursory and general discussion is that the accompaniment of songs, as also the arrangement of songs and incidental music, is not the job for "harmonium masters" and "ustads," but for regularly trained men who have a thorough knowledge of the arts of instrumentation and orchestration and understand both the Indian and the Western systems of music. ${ }^{28}$

\footnotetext{
${ }^{28}$ This excerpt is taken from an article written under the pseudonym "Musical Director" (1933, 29-30). Other than having strong opinions on film music, there is nothing about the article that can actually verify whether the writer was actually employed as a music director. In any case, it is significant that this title was chosen whatever the author's identity may have been.
} 
This was an argument for the professionalization of film music as something new and distinct from the music masters of the Indian stage or concert circuit. The music director promoted the idea of film music as its own specialized field of music, characterized, in part, by the orchestration of both Indian and European instruments in combination with vocal leads. In particular, he considered the Calcutta studio, New Theatres, to be the most successful in handling the orchestration of Indian music according to a judicious "mixing" of an almost unlimited variety of both Indian and European instruments (Musical Director 1933). ${ }^{29}$ Very early on, many of those involved in the production of film songs conceived their own project as distinct from that of stage performances and requiring an even more synthetic approach. Indeed, the very title music director to refer to someone who selected, arranged, and organized the production of film songs was unique to the context of film production and reflected this new professional musical specialty.

By the end of the 1930s, film songs had emerged as a music genre in itself, immediately identifiable as that of the cinema and yet quite distinct from any Tamil drama song styles. Indeed, the music of the Tamil stage to this day remains largely confined to the harmonium- and percussion-based sound that had already been established by the 1930s. In contrast, film songs continued to get more complicated, with orchestral compositions using a greater variety of musical instruments, arrangements, styles, and steadily improving recording technologies.

\section{Film Song Ascendancy}

This section charts the changing status of Tamil drama in relation to the increasing integration of the recording and cinema industries. Tamil cinema heavily relied on Tamil drama, but it was also responsible for changing, displacing, and marginalizing this very same drama. During the 1930s, virtually all Tamil drama companies were absorbed into the cinema industry in one way or another. Most drama performers joined or attempted to join the Tamil cinema. Furthermore, almost all of the old drama theaters were converted for the purposes of film exhibition, which proved a more affordable, profitable and popular entertainment. ${ }^{30}$ The popularity and profitability of professional drama, which had only a decade earlier been at the height of its public demand, began to suffer.

Already in 1935, an editorial in an early Tamil film journal reported that "[i]t is common knowledge that at present, when more and more talkies are being made, there is a lack of response to drama. At times one wonders, looking at

\footnotetext{
${ }^{29}$ This point about the eclecticism of Indian film music has been picked up more recently by both William Beeman (1980) and Alison Arnold (1988).

${ }^{30}$ This claim was made by the south Indian cinema exhibitor A. Narayanan in the Report of the Indian Cinematograph Committee, 1927-28 (Government of India 1928, 295).
} 
the craze for cinema, there may come a time when drama doors might have to be locked permanently" (Narayanaswamy 1935). By 1941, the fortunes of company drama had diminished so precipitously that an editorial in another Madrasbased cinema journal pronounced that the cinema had "completely killed the Stage in the South" (Srinivas 1941). These claims were exaggerated, as Tamil musical dramas continue to be performed, especially in the provincial circuits throughout south India. ${ }^{31}$ However, this exaggeration nonetheless conveyed a sense of the unexpected and dramatic success of the cinema in relation to the marked decline in popularity of the Tamil stage.

Over the course of the 1930s, the growing partnership between the south Indian record companies and Tamil cinema marginalized the music of stage dramas. By the end of the 1930s, Tamil film songs had decisively replaced drama songs and record sets as the main Tamil offering of the south Indian gramophone companies. From this point onward, Tamil drama music was greatly marginalized within the overall output of the music recording industry. The partnership between the recording industry and Tamil cinema left drama styles behind in order to produce film songs as the dominant musical commodity of the emergent Tamil mass culture. By the end of the decade, the partnership between the recording companies and the cinema industry had largely bypassed drama sources and styles in creating films songs. At the very moment when Tamil dramas and their stars moved into Tamil cinema, this new medium and its songs began to refigure the popularity of the former. But more than eclipsing drama music, the emerging popularity of film songs reorganized the entire field of Tamil music around the cinema. By the late 1930s, film songs, compared to all other kinds of south Indian musical practices, had already reached unprecedented popularity. Through films, recordings, radio broadcasts, and printed songbooks, Tamil film songs were more widely available and reproduced than any other form of music.

The expanding public profile of film songs created a new, imagined community of music listeners, refashioning the established class distinctions of musical taste. When, through the vehicle of film songs, humble rickshaw pullers were able to sing classical Karnatic tunes, the sudden and new ubiquity of Tamil film songs seemed to threaten the conventional hierarchies of musical taste (Ranga Rao 1976-77, 40-41). For south Indians with a vested interest in other kinds of music, the massive popularity of film songs seemed to endanger the existence of their preferred kind of music. Not surprisingly, the main opposition to film songs came from the Karnatic music establishment and was largely confined to an elite minority. ${ }^{32}$ For example, in his presidential speech to the 1941 Madras

\footnotetext{
${ }^{31}$ See Susan Seizer (2000) for an account of the reduced circumstances of contemporary musical drama.

${ }^{32}$ For a more general discussion of the Karnatic music establishment and its leading institution, see Lakshmi Subramanian (1999).
} 
Music Conference, Professor Venkataswami Naidu gave a stern warning about the dangers posed by the popularity of cinema music: "The great hold of the Talkies over the masses is a menace to the purity of Karnatic music." 33 For some critics, the problem was that as Karnatic music became more widely available, the subtlety, refinement, and sophistication of the music would be lost on untrained and uninitiated audiences (Sastri 1938). The perception that the prominence of film songs would degrade musical standards and taste was part of a concerted effort on the part of the elite Karnatic music establishment to refine its music monopoly as a classical, high-brow, and religious form and to distinguish it from the common commercial music of Tamil cinema. ${ }^{34}$ The emergence of Tamil film songs thus helped to redefine a hierarchy of music practices.

In less than a decade, the collaboration of drama, gramophone, and cinema produced a new regime of film song dominance at the center of an emergent cultural industry built around Tamil cinema. Film songs went beyond any previous identification with other kinds of music to become an entirely new, distinct, and creative musical genre. In describing the process by which film songs were selected, one contemporary music critic identified a reversal whereby the combination of gramophone and cinema reproductions had come to set the standard for live music performances:

The Talkie director chooses a few gramophone plates for the studio composer and he is to compose a song conveying the required ideas and the composition is to be shoved into the tune of the selected plate. More often than not the composer selects a piece from some printed matter and the song is made to order.... The result is that we have many mushroom songs in strange tunes interspersed with flat stilted words without points for appreciation except perhaps the voice of the artist who sings them. The pity of it is that some of these songs have begun to be sung in music performances also. (Svaminathan 1939)

This author describes a kind of self-referentiality between the gramophone and cinema that no longer relied on the authenticity of live performance as a musical source. The musical reproduction set the new standard for live music performance. The mechanical reproduction of Tamil music was no longer merely a

\footnotetext{
${ }^{33}$ In the same account, the author also claims that cinema music replaced folk songs as the music of the laboring and lower classes: "Now-a-days coarse folk songs cannot be heard everywhere as they were before and [instead] labour-folk sing a hit from 'Chintamani' this month and next month one from 'Devata' is on everyone's lips' (Naidu 1941, 3).

${ }^{34}$ For example, throughout the 1930s and 1940s, contributors to the Journal of the Madras Music Academy and attendees at its annual conference regularly campaigned against the musical influence of film songs. This publicly vocal lobby made the denouncement of film songs a necessary part of cultivating Karnatic music. All of the prominent Karnatic musicians who had performed in Tamil films during the 1930s renounced all connection to Tamil cinema by the 1940s.
} 
derivative form but had emerged as a creative force and definitive mode of mass production.

By way of conclusion, I return to the question of music in Tamil cinema. I have posed my answer to the question of why music has been so important to Tamil cinema as a matter of how music was commercially and institutionally established as a necessary and defining aspect of Tamil cinema. The question of music in Tamil cinema does not, of course, have a single answer for all times and audiences but has been continuously mobilized at different historical conjunctures in ongoing and multiple struggles. Nor are music traditions abstract, free-floating, or stable entities. They are social practices and institutions rooted to particular historical situations, open to constant debate and experimentation. In this essay, I have traced the complex and changing relationships among Tamil musical drama, south Indian recording companies, and Tamil cinema to show how a mass culture of music was produced around Tamil cinema beginning in the mid-1930s.

More than just a continuation of musical drama, the gramophone industry and the emergent film industry produced a new culturally hegemonic massproduced music for south India that eventually marginalized musical drama and threatened the cultural hierarchy of classical Karnatic music. The rapid expansion of the south Indian gramophone business during the late 1920s and early 1930s mediated the relationship between stage drama and Tamil cinema, converged and collaborated in the beginnings of Tamil cinema, and helped to create film songs as an entirely new and distinct musical genre. Contemporary sources suggest the ways in which those in south India understood and contested the changing drama-gramophone-cinema nexus and the resulting mass culture of films songs. To contemporaries, the rise of Tamil cinema and the ubiquity of films songs both offered a democratic promise to make music accessible for everyone and threatened to upset the social and cultural hierarchies of professional drama and classical Karnatic music. These sources also mark the shift from the music boom of the $1920 \mathrm{~s}$ and early 1930s as it transformed into a cinema-based mass culture of music by the 1940s. This collaboration around film songs produced a new form and institutionalization of popular music at the center of an emergent cultural industry of Tamil cinema, which, in many ways, is still with us and still dominates to this day.

\section{Acknowledgments}

I would like to thank Sarah Hodges and M. S. S. Pandian for their generous comments and helpful criticism of earlier drafts of this essay. I also benefited greatly from the former editor, Ann Waltner, and the anonymous readers' reports and editorial guidance in preparing the final version of this article. I would like to thank Birgit Meyer and the other members of the Pionier Project (Modern Mass Media, Religion and 
Imagination of Communities at the Amsterdam School for Social Science Research at the University of Amsterdam) for their generous help and comments.

\section{List of References}

Ananthachari, Aккоor. 1938. Sriman S. G. Kittappa Carittiram [in Tamil]. 4th ed. Shengkottai: Kittappa Piracuralayam.

Armbrust, Walter. 1996. Mass Culture and Modernism in Egypt. Cambridge: Cambridge University Press.

Arnold, Alison. 1988. "Popular Film Song in India: A Case of Mass-Market Musical Eclecticism." Popular Music 7 (2): 177-88.

Barnouw, Erik, and S. Krishnaswamy. 1980. Indian Film. 2nd ed. New York: Oxford University Press.

Baskaran, S. Theodore. 1981. The Message Bearers: The Nationalist Politics and the Entertainment Media in South India, 1880-1945. Madras: Cre-A.

. 1991. "Music for the Masses: Film Songs of Tamil Nadu." Economic and Political Weekly 26: 755-58.

1996. The Eye of the Serpent: An Introduction to Tamil Cinema. Madras: EastWest Books.

Beeman, William O. 1980. "The Use of Music in Popular Film: East and West.” India International Centre Quarterly 8 (1): 77-87.

Chandavarkar, Bhaskar. 1987. "The Tradition of Music in Indian Cinema: Birth of the Film Song." Cinema in India 1 (2): 7-11.

Chozhanadan, P. 2002. Kodumudi kolilam K. B. Sundaramabal Varalaru [in Tamil]. Chennai: Rishabam Pathippagam.

Cousins, Margaret. 1935. The Music of Orient and Occident: Essays towards Mutual Understandings. Madras: B. G. Paul.

Funny Magazine. 1934. Review of Sati Sulochana [P. Sambanda Mudaliar, Bharat Laxmi Pictures, Calcutta, 1934]. October 5.

Garga, B. D. 1996. So Many Cinemas: The Motion Picture in India. Mumbai: Eminence Designs.

Gomery, Douglas. 1980. "Economic Struggle and Hollywood Imperialism: Europe Converts to Sound." Yale French Studies 60: 80-93.

Government of India. 1928. Report of the Indian Cinematograph Committee, 19271928. New Delhi: Government of India Press.

Hansen, Kathryn. 1992. Grounds for Play: The Nautanki Theatre of North India. Berkeley and Los Angeles: University of California Press.

. 2000. "The Migration of a Text: The Indar Sabha in Print and Performance." Sangeet Natak, no. 127-128: 3-34.

Hansen, Miriam. 1985. "Universal Language and Democratic Culture: Myths of Origin in Early American Cinema" In Myth and Enlightenment in American Literature: In Honor of Hans-Joachim Lang, ed. D. Meindl and F. Horlacher, 321-51. Erlangen: University of Erlangen-Nürnberg.

Hughes, Stephen P. 2002. “The 'Music Boom’ in Tamil South India: Gramophone, Radio and the Making of Mass Culture." Historical Journal of Film, Radio and Television 22 (4): 445-74.

Jayarama Aiyer, T. K. 1938. "Music and Tempo." Talk-a-Tone, April, 34-35. 
Jones, Andrew F. 2001. Yellow Music: Media Culture and Colonial Modernity in the Chinese Jazz Age. Durham, N.C.: Duke University Press.

Joshi, G. N. 1980. "The Phonograph Comes to India." Cinema Vision India 1 (4): $40-45$.

1988. "A Concise History of the Phonograph Industry in India." Popular Music 7 (2): $147-56$.

Kapur, Anuradha. 1993. “The Representation of Gods and Heroes: Parsi Mythological Dramas of the Early Twentieth Century." Journal of Arts and Ideas 23/24: 85-107.

Khanna, R. C. 1927. "Evolution of the Hindi Stage" In The First All India Drama Conference at the Amateur Dramatic Association, 1921, ed. C. R. Reddy, 46-52. Bangalore: B. Sreenivasa Iyengar.

Kinnear, Michael. 1994. The Gramophone Company's First Indian Recordings, 18991908. Bombay: Popular Prakashan.

LeE, LeO Ou-Fan. 1999. Shanghai Modern: The Flowering of a New Urban Culture in China, 1930-1945. Cambridge, Mass.: Harvard University Press.

Manuel, Peter. 1988. "Popular Music in India: 1901-86.” Popular Music 7 (2): 157-76.

—. 1993. Cassette Culture: Popular Music and Technology in North India. Chicago: University of Chicago Press.

Musical Director [pseud.]. 1933. "Music in Indian Films: Song Accompaniment.” The Cinema, September, 29-30.

Myleru, C. R. 1934. “The Tamil Drama (Part 2)." Journal of the Annamalai University 3 (1): $71-78$.

Nagara Rao. 1933. “Andhra Talkies.” Filmland, June 3, 8-11.

Naidu, Venkataswami. 1941. "Presidential Address." Journal of the Madras Music Academy 12 (1-4): 4-8.

Narayanaswamy, B. R. 1935. Editorial. Cinema Ulagam [Cinema World; in Tamil], June 9.

Orr’s Gramophone and Talkies. 1938. Vishnu Leela, or the Story of Jaya and Vidya. Madras: Orr's.

OrR's and Sons. 1949. Turn of the Century, 1849-1949: P. Orr \& Sons. Madras: Orr's. Ranga RaO, V. A. K. 1976-77. "Tamil Film Music: The Rickshah Pullers Sang Karnatic 'Ragas." Filmfare, December-January, 40-41.

—. 1986. "The Sounds of Telugu Film Music" In Telugu Cinema: An Anthology of Articles, ed. K. N. T. Sastry, 39-63. Madras: Cinema Group.

Renade, Ashok. 1980. “The Extraordinary Importance of the Indian film Song." Cinema Vision India 1 (4): 4-11.

Sambanda MuthaliYar, P. 1932. Natakamedai Ninaivukal, Part One [in Tamil]. Chennai: Peerless Press.

Sastri, G. Tyagaraja. 1938. "Musical Programmes: How to Improve Them." The Hindu, June 14, 16.

SAwhney, R. C. 1933. “A Talk about Our Talkies.” Cinema, June, 33.

Seizer, Susan. 2000. "Roadwork: Offstage with Special Drama Actresses in Tamilnadu, South India." Cultural Anthropology 15 (2): 217-59.

Shanmugam, Avvai T. K., ed. 1967. Tamizh Natakametai Cankaratas Suvamikal Nuttandu Vizha Malar, 1867-1967 [in Tamil]. Chennai: Tavattiru Cankaratas Cuvamikal Ninaivu Manram.

—. 1972. Enathu Nataka Vazhkkai [in Tamil]. Chennai: Vanathi Patippakam.

_. 1978. "Natakamum Tamilicaiyum.” In Nataka Chinthanaigal [in Tamil]. Puthaneri R. Subramaniam, ed. Chennai: Vanathi Patippakam. 


\section{Stephen Putnam Hughes}

Skillman, Teri. 1988. "Songs in Hindi Films: Nature and Function.” In Cinema and Cultural Identity: Reflections on Films from Japan, India, and China, ed. W. Dissanayake, 149-58. Lanham, Md.: University Press of America.

SRinivas, N. 1941. "Murder on the Screen." Talk-a-Tone 4 (12): 7-9.

Srinivasan, R. 1962. Facets of Indian Culture. Bombay: Bharatiya Vidya Bhavan.

Subramanian, Lakshmi. 1999. "The Reinvention of a Tradition: Nationalism, Karnatic

Music and the Madras Music Academy, 1900-1947." Indian Economic and Social History Review 36 (2): 131-63.

Subrahmanya Ayyar, C. 1945. My Musical Extravagance. Madras: Publisher unknown. Svaminathan, R. 1939. “The Cart Before the Horse." Journal of the Madras Music Academy 10: 1-4.

Twin Record Co. 1933. Record Catalogue. Dum Dum: Twin Record Co.

Williams, A. 1992. "Historical and Theoretical Issues in the Coming of Recorded Sound to the Cinema." In Sound Theory, Sound Practice, ed. Rick Altman, 126-34. New York: Routledge.

YАJNIK, R. K. 1933. The Indian Theatre: Its Origins and Its Later Developments under European Influence. London: Allen \& Unwin.

Zhang, Yingjin. 1999. Cinema and Urban Culture in Shanghai, 1922-1943. Stanford, Calif.: Stanford University Press. 